\title{
Do Offenders Deserve Proportionate Punishments?
}

\author{
Göran Duus-Otterström ${ }^{1,2}$ (B)
}

Accepted: 12 April 2021 / Published online: 20 April 2021

() The Author(s) 2021

\begin{abstract}
The aim of the paper is to investigate how retributivists should respond to the apparent tension between moral desert and proportionality in punishment. I argue that rather than attempting to show that the term 'proportionate punishment' refers to whatever penal treatment the offender morally deserves, retributivists should maintain two things: first, that a punishment is proportionate when it is commensurate to the seriousness of the crime; second, that offenders morally deserve proportionate punishments. This view requires adopting a local theory of desert as opposed to a holistic one. In the second part of the paper, I argue that there are indeed good reasons to adopt a local theory of desert. Once retributivism is seen through the lens of local desert, there is no obvious mistake in saying that offenders morally deserve punishments that are proportionate to the seriousness of their crimes.
\end{abstract}

Keywords Desert · Proportionality $\cdot$ Punishment $\cdot$ Retributivism

As indicated by the title of the essay, I am interested in whether people morally deserve proportionate punishments for criminal wrongdoing. This question may seem confused since, given the way these terms are often used, a 'proportionate' punishment is precisely what an offender morally deserves for a criminal wrong. Yet there are situations in which proportionality and moral desert appear to come apart. The most obvious examples involve people who have led morally decent lives despite being unjustly treated at the hands of their community but then commit a one-off crime without excuse or justification. In such situations, to mete out a punishment that matches the seriousness of the criminal act seems to clash with the idea that punishment should be appropriate given the moral worth of the offender. When the offender's life already contains more than enough hardship, we might think that

Göran Duus-Otterström

goran.duus-otterstrom@pol.gu.se

1 Department of Political Science, University of Gothenburg, Box 711, 41123 Gothenburg, Sweden

2 Institute for Futures Studies, Stockholm, Sweden 
a proportionate punishment, while perhaps necessary for other reasons, would be more than the offender morally deserves. ${ }^{1}$

My aim in this paper is to investigate how retributivists should respond to this apparent tension between moral desert and proportionality. The question is an important one since retributivists typically believe both that (negative) moral desert plays a role in explaining why punishment is permissible or desirable and that punishments should be proportionate to the crime. I argue that retributivists should indeed answer that proportionate punishments are morally deserved. That is, rather than trying to convince us that the term 'proportionate punishment' refers to whatever penal treatment the offender morally deserves, retributivists should maintain two things: first, that a punishment is proportionate when it is commensurate to the seriousness of the crime; second, that offenders morally deserve proportionate punishments. I call this view proportionalism.

Now in itself this argument is probably unsurprising. To the extent that retributivists have pondered the relationship between proportionality and moral desert, I suspect most have thought along the lines of proportionalism. Yet proportionalism requires a careful defense of a 'local' theory of desert, because there is an unavoidable clash between proportionality and desert if we understand desert holistically. Much of the discussion that follows, therefore, aims to show that we should reject the so-called whole-life theory of desert in favor of the local theory. Some think that the whole-life theory is a particularly compelling account of desert, and that retributivism is greatly weakened by its inability to coexist with this theory. I argue that the local approach to desert is actually more plausible. If I am correct in this, then this is welcome news for retributivists, because it clears a path for equating proportionate punishments with an offender's penal desert.

\section{Proportionality and Desert}

The topic of this paper, then, is the relationship between proportionality and moral desert in the context of legal punishment. Let us begin by defining the two concepts more carefully. ${ }^{2}$

Claims of moral desert are traditionally thought to take a three-place form according to which an actor $S$ deserves some object $O$ in virtue of some desert base $B$, such that it would be morally good in and of itself that $S$ receive $O .^{3}$ There is

\footnotetext{
${ }^{1}$ In explaining the intuition that someone morally deserves a disproportionately lenient punishment, it can be tricky to separate the offender's moral desert from whether a would-be punisher has the right to treat her according to her moral desert. When the offender has been treated unjustly, we might find a lenient punishment is called for simply because the community has lost the moral standing to punish her. For recent overviews of this debate, see Duus-Otterström \& Kelly (2019) and Fritz (2019). I here want to speak only about the content of moral desert. Thus, I assume that while unjust treatment is potentially relevant for what a person deserves (e.g. how severe a punishment), it is not relevant for whether others are morally permitted to bring this about.

2 The following two paragraphs draw heavily on Sher (1987), Feinberg (1999) and Olsaretti (2003).

3 I borrow the term 'desert object' from Berman (2013).
} 
great variety among ways of filling out this formula, but generally $S$ is taken to be a person and $B$ an action or set of actions that $S$ has already performed and which is relevant to a moral assessment of $S$, particularly as regards her moral virtue. Saying more at this point would be unwise since there is substantial disagreement about the proper domain of a theory of moral desert. Suffice it to say here that moral desert typically links certain desert objects — states of affairs or modes of treatment- to the moral worth of people's actions. The idea is that when someone morally deserves some object in virtue of her actions, then it would be morally good in and of itself if she got that thing. Put differently, morally deserved outcomes have non-instrumental and impersonal value: they are good in themselves and need not be good for anyone. ${ }^{4}$

It is important to be clear about exactly what we mean when we talk about moral desert, for there are several ways we use the term 'desert' in ordinary language. We say, for example, that a student deserves a good grade for writing a good term paper, or that the fastest runner deserves to win the race. Such remarks typically refer to institutional desert in that they point to what people are entitled to given the way an institution or practice is set up. Institutional desert is famously different from moral desert, but the key difference between them is not, as it is sometimes claimed, that institutional desert sees deserved outcomes as merely owed. After all, it is conceivable that satisfying institutional desert can be morally good in and of itself. What is distinctive about moral desert is instead the insistence on that the desert base must draw on the moral quality of someone's character or actions. ${ }^{5}$ When we say that a student morally deserves a good grade, we have in mind something like the fact that she worked hard. If the student effortlessly wrote an excellent term paper in virtue of sheer inborn talent, we would not say that she morally deserves a good grade although she is entitled to one given the prevailing grading criteria. Since I speak of moral desert throughout the paper, from now I drop the prefix and write just 'desert'.

What does this mean for punishment? When we say that a person 'deserves' a punishment, the point is that giving her this punishment would be morally good in and of itself considering the moral quality of her actions or character. More specifically, the punishment is optimal from the point of view of desert. Talk of 'morally deserved' punishment sometimes admittedly refers to the weaker idea that punishment must not exceed the maximum penalty to which the offender is morally liable, but the kind of deserved punishments at stake in the paper are those that would be best from the point of view of desert. Hence, I take the claim 'person $S$ deserves punishment $P$ ' to mean that any punishment greater or lesser than $P$ would be inferior to $P$ from the point of view of desert. ${ }^{6}$

\footnotetext{
${ }^{4}$ Note that saying that morally deserved outcomes have such value is not the same as saying that they have great value. As Husak (2016) argues, desert might play a small role in what we should do all things considered.

5 Some also take moral desert to refer to a specific desert object, namely well-being (Kagan 2012). I am skeptical of this idea for reasons given below. In my view, although moral desert is a function of the moral quality of one's actions or character, this is compatible with a plurality of desert objects.

6 Some prefer to say that criminal wrongdoers deserve suffering rather than punishment, arguing that this avoids circularity. I set this issue to one side, but see Berman (2011) for a nice discussion.
} 
Consider next proportionality. This refers to matching relationship between the severity of a punishment and the seriousness of the crime: we say that a punishment is 'proportionate' if and only if its harshness is commensurate to the gravity of the offense. ${ }^{7}$ The classical account of proportionality thus understood is lex talionis, or the principle that the harm one inflicts on others should be inflicted in return. Contemporary penologists, however, hold the more sophisticated view that a punishment is proportionate if and only if its severity is commensurate to the seriousness of the crime, where seriousness is some function of the harm or wrong caused or risked and the offender's culpability (see e.g. Moore 1998, p. 192; Duff 2001, p. 135; Husak 2008, p. 182; Matravers 2020, p. 77). ${ }^{8}$ From this account, then, a killing is more serious than assault; an intentional killing is more serious than a negligent killing; and so on.

Why would proportionality and moral desert thus defined be in conflict? The reason is that the determinants of a person's deservingness of punishment seem broader than the factors that go into deciding how serious a criminal act is. The bank robber who is nice to pets and senior citizens in everyday life, for example, appears more deserving than an otherwise identical bank robber who is not. Yet being nice to pets and senior citizens in everyday life does not make one's bank robbery any less serious. The seriousness of a crime is determined by the harm caused or risked and the offender's culpability, not by whether someone is a 'nice guy'. In that way, proportionality seems a narrower notion than desert.

How could one respond to the tension? Some might just happily accept it. Indeed, some prominent defenses of proportionate punishment have no apparent use for the concept of desert in the first place. If punishment is supposed to communicate 'the degree of reprehensibleness of the [criminal] conduct' (von Hirsch 2009, pp. 118-19), for example, it is arguably irrelevant whether offenders deserve the punishments that send the right message. Retributivists, however, are committed to both desert and proportionality. They need to show why proportionality and desert are co-extensive in the case of punishment after all. One possibility is to opt for the view we could call,

Desertism. Any punishment that is deserved is also, thereby, proportionate.

Desertism resolves the tension between proportionality and desert by making the concept of proportionality completely derivative of desert. Suppose we are dealing with an unjustly impoverished offender ('Aaron') whose criminal wrongdoing, though serious, is a departure from an otherwise morally upstanding life. Suppose further that the judge decides to mete out an unusually lenient sentence because she is moved by Aaron's life history. On desertism, the central question is whether Aaron deserves the unusually lenient sentence. If the answer is yes, then the sentence is

\footnotetext{
7 'Commensurate' here can be vague between absolute and relative proportionality (Duus-Otterström 2020). I have absolute proportionality in mind in the paper.

8 There is considerable disagreement within this framework about the role of actual harm for criminal seriousness (Alexander and Ferzan 2009; Moore 2010) and about the relationship between harm and culpability (Ryberg 2020). I set these matters to one side here.
} 
proportionate, no matter what we might think about it pre-theoretically. It is proportionate because it matches, or stands in proportion to, Aaron's negative desert, not because it fits the crime as such.

Desertism should be rejected. In making proportionality a conceptual slave to desert, it is at odds with deeply entrenched ordinary intuitions about proportionate punishment. Indeed, given the right configuration of facts, desertism is compatible with saying that a slap on the wrist is the proportionate punishment for murder. ${ }^{9} \mathrm{My}$ sense is that while it is conceivable that some murderers deserve an insignificant punishment, it is simply implausible to think of this as a proportionate punishment as opposed to a disproportionately lenient but deserved one. After all, the reason everyone immediately recognizes 'ten eyes for an eye' as clashing with proportionality is that we associate proportionality with the fit between the wrong and the response. It seems to me that we can and should talk about whether a punishment is proportionate irrespective of whether this treatment is deserved.

Since desertism is not viable, the remaining option to reconcile proportionality and desert is to defend,

Proportionalism. Proportionate punishments are punishments whose severity is commensurate to the seriousness of crimes. Offenders deserve proportionate punishments.

Unlike desertism, proportionalism retains the standard idea that a punishment is proportionate when its severity matches the seriousness of the crime. The challenge for this view is of course to explain why proportionate punishments so understood are necessarily deserved. Indeed, proportionalism may seem a complete nonstarter since, as a long list of critics have noted, there is little reason to think that implementing a scheme of proportionate punishment would be wise if our aim is to treat people as they deserve. Even if retributivists could somehow explain why punishment should be reserved for the guilty, so the argument goes, it is extremely unlikely that punishing the guilty according to the seriousness of their crimes would be good from the point of view of desert. Since a person's desert is the product of many factors which must be considered in combination, to single out an isolated criminal act, as proportionality would have us do, is too narrow and therefore bound to lead to undeserved treatment. W.D. Ross summarized the problem well when he noted that 'the criminals that a retributive theory of state punishment would call on us to punish ... may well be persons who are more sinned against than sinning, and may be, quite apart from our intervention, already enjoying less happiness than a perfectly fair distribution would allow them' (Ross 2002 [1930], p. 59). ${ }^{10}$

Whether proportionalism is too narrow depends on one's theory of desert. I will argue that there is a plausible theory of desert that vindicates the idea that people can deserve proportionate punishments for criminal acts considered in isolation. The

\footnotetext{
9 Or that life imprisonment is the proportionate punishment for shoplifting.

${ }^{10}$ The criticism is also developed by, for example, Ryberg (2004), Tadros (2011, pp. 66-73), and Kolber (2020). These theorists do not subscribe to the whole-life theory; they simply argue that this is the theory to which retributivists are committed. See also Sher (1987, pp. 82-90, pp. 132-149).
} 
critics argue, however, that when we judge how a person deserves to be treated, we must consider all of her deeds and not just an isolated act. Indeed, the critics of proportionalism typically subscribe to the ultra-holistic theory of desert called,

The whole-life theory of desert. People deserve that their lifetime well-being corresponds to their lifetime virtue.

Following the whole-life theory, we first consider the level of virtue and vice embodied in a person's life up to some point in time. We then consider the sum of well-being (e.g. happiness) the person has enjoyed up to the same point. Finally, we assess whether the well-being matches the level of virtue. What people deserve is that their lifetime well-being corresponds to their lifetime virtue. ${ }^{11}$

Before discussing why the whole-life theory clashes with proportionalism, it is worth noting that the theory is not the only holistic account of desert. We can distinguish between accounts of desert along two axes, one spatial and one temporal. Let us call a theory of desert that for the purposes of judging what a person deserves counts all deeds a 'wide' theory of desert and a theory that looks at isolated deeds a 'narrow' theory of desert. Let us further call a theory of desert that counts past deeds a 'diachronic' theory and a theory that only looks at present deeds a 'timesliced' theory. ${ }^{12}$ Since the temporal and spatial axes are logically independent, as Fig. 1 shows we can distinguish between four different types of desert theory, and the claim that we should be 'holistic' about desert is ambiguous between boxes 3 or 4. A theory of desert could count all of a person's deeds while restricting the temporal extension of that calculus, say because it takes an episodic approach to morality. On such a view, what someone deserves will be a function of all of their good and bad deeds in the recent past.

Yet, the reason to count all deeds in the present-some kind of 'completeness' typically also generates a reason to count deeds over time. Therefore, a holistic approach to desert typically occupies box 4 in the figure. The whole-life theory is the paradigmatic example of a box 4 view since it takes all deeds, past or present, to be relevant for judging what a person deserves. The local theory I will espouse occupies box 1, though as I shall note it could also be developed as a diachronic view and thus occupy box 2 .

Having noted that references to a 'holistic' approach to desert can be ambiguous, let us now turn to the clash between the whole-life theory and proportionalism. The reason the whole-life theory is incompatible with proportionalism is that there is no reason to think that inflicting proportionate punishments on offenders would bring their lifetime well-being and lifetime virtue into alignment. What if (to take just one example) we are dealing with a one-time offender whose long list of good

\footnotetext{
11 Strictly speaking, the important thing is the outcome at the end of a person's life, but since we do not know whether an undeserved excess or lack of well-being will be offset by later on, it is reasonable to take the whole-life theory as saying that there should be a continuous match between a person's wellbeing and moral virtue.

12 These are simplifications because the axes are dimensions, but writing about them as categories is easier and does not obscure the point that references to 'holism' can be ambiguous.
} 
deeds have gone unrewarded, such that their pre-crime sum of well-being was much lower than it ought to have been? To be sure, committing a criminal wrong affects one's level of moral virtue negatively and so is a reason one should be faring less well according to the whole-life theory. But the question is whether inflicting a proportionate punishment would be good from the point of view of desert in a holistic sense, and since there is a difference between the seriousness of a crime and a person's lifetime moral virtue, the whole-life theory at best gives us a contingent justification for proportionate punishments. Indeed, if we adopt the whole-life theory, we may find ourselves having desert-based grounds to abolish the institution of legal punishment altogether.

So proportionalism is hopeless if we adopt the whole-life theory. But why must we adopt the whole-life theory? The obvious alternative is to argue that people deserve punishments not because of their lifetime well-being and moral virtue but because of having committed a criminal wrong. That is, retributivists could instead embrace:

The local theory of desert. People deserve particular kinds of treatment in virtue of context-specific desert bases.

This is just an empty formula that needs fleshing out, but it should immediately be clear how taking a 'local' approach could resolve the tension between proportionate punishments and desert. If what people deserve for criminal wrongdoing turns on a context-specific desert base, and the context-specific desert base with respect to legal punishment is the seriousness of one's crime, then it is not puzzling why people deserve proportionate punishments.

The question, though, is whether it is plausible to abandon the whole-life theory in favor of the local theory. While the latter is not without defenders-I take it that Joel Feinberg's seminal essay 'Justice and Personal Desert' (1999 [1963]) and George Sher's Desert (1987) espouse local theories, for example-it has been argued that the whole-life theory is the 'most attractive' (Tadros 2011, p. 73) and 'elegant' (Kolber 2020, p. 185) account of desert. The whole-life theory certainly has an impressive intellectual pedigree. It is endorsed by eminent historical thinkers such as Leibniz, Kant, Sidgwick and Ross (Feldman and Skow 2020) as well as by the most penetrating work on desert to date, Shelly Kagan's book The Geometry of Desert (2012). ${ }^{13}$ The reason the whole-life theory garners support is that it is thought to explain important moral beliefs, in particular the idea that it is good in and of itself when the virtuous fare better than the vicious. The argument is that unless we adopted the whole-life theory, we could not explain, for example, that serial wrongdoers deserve greater punishment than morally decent first-time offenders for committing similar crimes.

Remarks like these could lead us to think that retributivists would be ceding something centrally important if they were to abandon the whole-life theory-they

\footnotetext{
13 While Kagan does not restrict his arguments to the whole-life theory, he does note that the main object of moral desert is well-being, that the predominant basis for moral desert is virtue, and that counting desert across whole lives seems 'preferable' (2012, pp. 6-12).
} 
Fig. 1 Four types of desert theory
Time-sliced Diachronic

\begin{tabular}{|c|c|c|}
\hline Narrow & 1. & 2. \\
\hline Wide & 3. & 4. \\
\hline
\end{tabular}

would resolve the tension between desert and proportionality by, as it were, butchering the real meaning of desert. I want to argue that this is mistaken. In my view, the local theory offers a more compelling account of desert. I argue for this claim in the next two sections. My strategy is to show that the whole-life theory faces significant difficulties that the local theory avoids and that the objections that can be directed against the local theory are less worrisome in comparison.

\section{Rejecting the Whole-Life Theory of Desert}

To see why the whole-life theory is implausible, consider the following case:

Helpful Scoundrel. Bert has lived his life in a selfish and ruthless way, using deceit and dirty tricks to pursue a successful corporate career. The strategy has worked; Bert has never gotten his comeuppance but has led a comfortable and happy life. One day, on the way to a business meeting, Bert notices a dog escaping from the leash of a passerby. The dog runs into the street. Upon seeing this Bert, suddenly and totally out of character, rushes into the street and saves the dog from the oncoming traffic. He does this without ulterior motive: he genuinely wants to help the dog and its owner.

Suppose that saving the dog was neither morally required nor socially normal in the sense that it is just 'what anyone would do' when witnessing a similar situation. Suppose further that saving the dog involved a non-trivial risk to Bert. Does Bert then deserve praise or gratitude for his act? It seems to me that the answer is yes. Bert did a nice thing at a risk to himself. Surely, he deserves to be praised or thanked for this, despite being a bad person in general. The whole-life theory, however, cannot explain this. Bert's lifetime well-being, we can safely assume, far exceeds his moral virtue. According to the whole-life theory, therefore, Bert should fare worse and not better. True, in rescuing the dog, Bert's level of moral virtue improves, making his happiness less problematic than it was before. But it is not plausible that the act of rescuing the dog totally redeems Bert: he is presumably still better off than he deserves to be given his overall moral virtue. This means that Bert does not deserve praise or gratitude for rescuing the dog according to the whole-life theory. Indeed, if the dog owner knew all the facts, she would see that it would be better to actively reduce Bert's well-being, say by insulting him. This is quite counterintuitive. 
Defenders of the whole-life theory will no doubt reply that the Helpful Scoundrel case simply does not speak to their theory since the case asks us to consider whether someone deserves praise or gratitude and not whether someone deserves to be faring well. The idea is that since the whole-life theory focuses specifically on wellbeing, it can grant that Bert deserves praise or gratitude for rescuing the dog without undermining the separate point that he also deserves a less happy life.

This would be a good response if praising or thanking someone and making them happy were always two separate things, but this is clearly incorrect. We can and typically do enhance people's happiness by praising them or offering them a heartfelt thanks. This blocks the idea that the whole-life theory can explain why someone like Bert deserves praise or gratitude just because the theory focuses on wellbeing. Indeed, the notion of separating out people's well-being from the way they are treated is odd to begin with since one's well-being in large part depends on the way one is treated. According to the whole-life theory, if a heartfelt thanks from the dog owner would make Bert happier, it would not be deserved for the indirect reason that it would bring about undeserved happiness.

There are only three situations in which the whole-life theory could say that praising or thanking Bert for rescuing the dog would be consistent with his desert. The first is if praising or thanking him would for some peculiar reason reduce his wellbeing. Praising or thanking him would then be deserved since it would bring about deserved unhappiness. The second is if praising or thanking him would leave his well-being unaffected. It would then be compatible with the whole-life theory to say that he deserves praise or gratitude for some reason other than overall moral virtue. The third is if we would offset the well-being improvement Bert would gain from praise or gratitude by reducing his well-being in some other way (e.g. kicking him on the leg immediately after thanking him). The first two situations are clearly unusual and the third is downright strange. Moreover, only the first describes an entailment of the whole-life theory; the other two merely show how the whole-life theory could coexist with some other account of desert which tells us that Bert deserves praise or gratitude. In the normal situation where praising or thanking Bert would make him happier, the whole-life theory is at odds with the idea that Bert deserves such treatment. It is also worth noting that even if the whole-life theory would somehow be able to say that Bert deserves praise or gratitude for rescuing the dog, it is unlikely that this will be for the right reasons, for the theory sees deservingness of praise and gratitude as contingent on its effects. It is plausible that Bert deserves gratitude from the dog owner independently of whether it affects his well-being, but this is not something the whole-life theory could say.

The whole-life theory could not be rescued from this result by disaggregating Bert's desert into claims about how he deserves to be treated by different agents. When we consider the Helpful Scoundrel case, it is natural to think that Bert deserves praise and gratitude specifically from the dog owner and scorn from those he has treated badly. However, while it seems true that desert can be 'agent relative' 
in this sense, it is not an idea the whole-life theory can help itself to. ${ }^{14}$ The whole point of the whole-life theory is that we should focus on overall well-being and overall virtue. Once the dog owner adopts this outlook and realizes that Bert fares better than he deserves, she would draw the same conclusion as everyone else, namely that thanking Bert would be bad from the point of view of desert if it would make him happier.

Someone might still want to defend the intuitive attractiveness of the whole-life theory by pointing out that if a nicer person than Bert had rescued the dog, then that person would have been more deserving of praise or gratitude than Bert. But on this point, I am quite prepared to bite the bullet. In my view, there is no difference between Bert and the nicer person in terms of their deserving praise or gratitude for saving the dog, since what they deserve to be praised or thanked for is the act of rescuing the dog and this is an act both Bert and his nicer counterpart performed. It seems to me, then, that the right thing to say is that either person would deserve praise or gratitude for rescuing the dog, but that Bert in addition would deserve scorn for his ruthless behavior.

\section{The Local Theory of Desert}

The reason the whole-life theory fares so badly in a case like Helpful Scoundrel is its monism, i.e. the fact that it makes virtually all questions of desert a matter of aligning moral virtue and well-being. It stands to reason, then, that a more plausible approach to desert is to reject monism. ${ }^{15}$ This is the main message of the local theory of desert.

The local theory of desert has two notable features. First, it adopts a pluralistic approach to desert. Whereas the whole-life theory treats desert as a relationship between one particular desert object (well-being) and one particular desert base (virtue), the local theory maintains that there are many different desert objects and that the desert base may well differ between them. We might say that, for the local theory, desert must be broken down into different 'spheres' of desert, where a sphere is defined in terms of a distinctive desert object and is governed by its own standard as to how the relevant object is allocated. The things that make someone deserving of gratitude, for example, are not necessarily the same as the things that make us deserving of punishment. This follows Feinberg's observation that 'the bases of desert vary with the mode of deserved treatment' (Feinberg 1999, p. 73). ${ }^{16}$

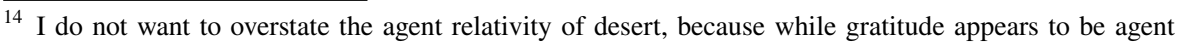
relative, this does not seem to hold for desert objects in general. To see this, suppose orbiting aliens happened to observe Bert as he rescued the dog. While it would have been odd for the aliens to think that they owed Bert a thank you before they zoomed off into space, they might well have had a desert-based reason to land and dish out some praise. The difference, if there is one, could be explained by Feinberg's (1999, p. 82) remark that 'anyone can admire or deplore'.

15 An additional ground to doubt the whole-life theory is that it is imperialistic: because it takes moral virtue to be relevant for the distribution of all sources of well-being, it makes almost everything a question of desert.

${ }^{16}$ Sher (1987) for the most part prefers to divide spheres of desert based on different desert bases (e.g. effort) rather than different desert objects.
} 
Second, the local theory insists on the mutual independence between spheres of desert. This stands in stark contrast with the fungibility that characterizes the wholelife theory. Suppose Betty performs a helpful act but once escaped punishment for a crime. The whole-life theory might here say that it would be good to withhold any expression of gratitude towards Betty as compensation for the fact that Betty escaped punishment in the past. The local theory, by contrast, maintains that desert must be disaggregated into mutually independent spheres, meaning that there is no master desert that allows for fungibility between all types of treatment. For that reason, rather than seeing not thanking Betty as an appropriate way to offset a prior mistake, the local theory will regard it as another violation of desert. To not thank Betty would add the error of ingratitude to the already existing error of insufficient punishment.

To be sure, this is a bare-boned account. To flesh out the local theory, much more would need to be said, for example, about how many 'spheres' of desert there are. Feinberg (1999) famously divided desert into five modes of treatment-prizes, grades, rewards and punishments, praise and blame, and compensation-but no doubt other lists could be drawn up. ${ }^{17}$ Likewise, more would need to be said about the desert bases that govern different spheres of desert. I do not need that kind of detail here, however, because the important thing for my argument is - apart from the reasonable assumption that punishment is a sphere of desert-just the idea that different spheres call for different and mutually independent allocations. It is this structural feature of the local theory that ensures that it provides a more plausible approach to desert. Consider again the case Helpful Scoundrel, in which it seemed intuitive that Bert deserves praise or gratitude for rescuing the dog despite being a bad person. The local theory is able to explain this precisely because it treats Bert's desert for rescuing the dog and for his ruthless behavior as two separate things. Since the local theory refuses to subsume all questions of desert under some kind of master desert, it allows that people can simultaneously deserve praise or gratitude for one act and blame for another.

The local theory resembles various local approaches to justice, such as those by Michael Walzer (1983) and Jon Elster (1990). These approaches sometimes come with controversial metaethical commitments, so it is important to note that we need not endorse conventionalism just because we accept that there are different spheres of desert. ${ }^{18}$ What the local theory shares with these approaches is just the (plausible) insistence that it would often be a mistake to allocate goods without recognizing their distinctive properties. This point is even more striking on a theory like Walzer's because it deals with distribution in general and not just with desert. Yet the same point stands even when we restrict out attention to desert, because just like we do not think that, say, winning a Nobel Prize should affect one's access to health care, we do not think that people who are rude to strangers cannot deserve good

\footnotetext{
17 Feinberg did not explicitly defend mutual independence between spheres of desert, but it is arguably implicit in his account. Sher is somewhat more explicit on mutual independence since he mentions that different kinds of desert can be incommensurable (see e.g. Sher 1987, p. 84).

18 I lay out my reasons against conventionalism about desert in Duus-Otterström (2018).
} 
grades for working hard on their term papers. To be sure, there are cases where disaggregation into mutually independent contexts of desert starts to look implausible. For example, it would be fanatic to insist on praising Bert for rescuing the dog if Bert were a mass murdering pedophile. But what drives these reactions is arguably that morally vicious people are so deserving of blame and punishment that it drowns out our reason to praise them for the good deeds they may nevertheless perform. We may think that someone deserves praise for an act but maintain that acting on this desert is insignificant given everything else that the person deserves.

Let us now return to proportionalism, the view that offenders deserve punishments that are proportionate to the seriousness of their crimes. We have seen that critics think that proportionalism is too narrow. The local theory shows that this criticism is wildly underspecified. On a local approach to desert, the question of whether proportionalism clashes with desert depends entirely on whether proportionality is an appropriate principle of desert in the sphere of punishment. Suppose we were to accept Mitchell Berman's account of deserved punishment, which says that:

An individual who engages in wrongdoing deserves that her life go less well than it otherwise would have gone, and less well in proportion to the blameworthiness of her wrongdoing, and that she understands that it goes less well as a consequence of her wrongdoing (Berman 2013, p. 88).

There would then be no tension between proportionality and desert. Getting a proportionate punishment is simply part of how desert works in relation to punishment. Complaining that punishment so conceived will fail to align well-being and virtue is just to fail to respect the plurality and mutual independence of spheres of desert. ${ }^{19}$

That proportionalism succeeds must of course be demonstrated. We cannot defend proportionalism without considering arguments for and against proportionality as the standard of local desert in the sphere of punishment. It is not part of my ambition here, though, to defend proportionalism as a substantive view (although I am inclined to think that it is correct). I merely want to point out that once retributivists adopt the local theory of desert, then a space is carved out that makes proportionalism a viable idea. There is nothing strange about saying that criminal wrongdoers deserve proportionate punishments because this could be the correct standard of desert in the sphere of punishment.

\section{Objections to the Local Theory}

Let me now respond to some objections to the local theory. The most obvious objection is that the local theory is unable to account for the fundamental attraction of desert, which is its likeness to divine justice. Consider the following passage from Adam Kolber:

${ }^{19}$ Berman (2013, p. 104) captures this point by calling retributivism a 'localized' theory of justice. 
The whole-life view has been likened to divine justice for a reason. When we picture divine justice, we tend to imagine an omniscient deity that dispenses good or bad treatment based on full knowledge of a person's desert. We might think the current-crime approach deficient to the extent that it ignores aspects of moral desert. What started as the relatively attractive intuition that good people deserve good things and bad people deserve bad things turns out to ignore much of (and probably most of) a person's moral desert. It's as if entry to the Pearly Gates were calculated only on weekend behavior while entirely ignoring weekday behavior (Kolber 2020, p. 190). ${ }^{20}$

Two (connected) points are being raised here. The first is that the local theory 'ignores aspects of moral desert.' The second is that the local theory is, thereby, unlike divine justice. I discuss them in order.

Kolber argues that taking a local approach to punishment would be a mistake because, in looking only at what a person deserves in virtue of committing a crime, we would ignore all the other determinants of a person's desert, including the fine qualities the person might have exhibited in other areas of life. The selective focus on the crime is especially problematic, Kolber argues, because it all but ensures that many offenders would be overpunished for their crimes. ${ }^{21}$ It is tantamount to treating someone according to their worst behavior without giving them credit for good behavior or for past hardships endured.

The key thing to note in response is that the local theory does not ignore aspects of desert as much as it compartmentalizes them. Suppose someone is simultaneously an extraordinarily selfless parent and guilty of a criminal wrong. Kolber seems to think that the local theory would somehow force us to ignore that people deserve credit for being selfless parents. But the local theory does no such thing, it only rejects that we must factor in someone's parenting skills when determining what she deserves for breaking the law.

Once we see that the local theory does not ignore aspects of desert any more than the whole-life theory does, we see that everything turns on whether compartmentalizing desert is plausible. If the answer is yes, then there is nothing structurally wrong with meting out proportionate punishments as far as desert is concerned. In particular we could not say that proportionate punishments are practically guaranteed to be undeservedly harsh. Kolber assumes that overpunishment means 'more than deserved given all of a person's deeds', but if we are right to compartmentalize desert and proportionalism is correct, overpunishment means 'more than deserved in light of the seriousness of the offender's crime'. A proportionate punishment then cannot be undeservedly harsh.

\footnotetext{
${ }^{20}$ By the 'current-crime approach', Kolber means roughly what I call proportionalism. It should be stressed that Kolber wants to reject the whole-life theory as well. A desert skeptic, his overall argument is that retributivists cannot formulate a satisfactory answer to various 'time frame' problems. Still, he thinks the whole-life theory better captures what seems attractive about desert.

21 Kolber assumes that overpunishment is a worse error than underpunishment for retributivists. I agree with this (Duus-Otterström 2013).
} 
This brings us to Kolber's claim that the local theory does not look anything like divine justice. On this score, I am in agreement with Kolber. Since the local theory treats our desert as occurring over a series of local allocations, each in accordance with the logic that is appropriate for the treatment in question, it does not resemble the kind of comprehensive weighing up we imagine would take place at the Pearly Gates. But unlike Kolber I suspect this might be a feature of the theory rather than a flaw. We have seen that refusing to disaggregate desert leads to problems, such as thinking that bad people can never deserve praise or gratitude. To the extent the whole-life theory mimics divine justice, then, there is reason to question how just divine justice really would be.

I recognize, however, that the divine justice metaphor is compelling. The reason many are attracted to desert in the first place is that they believe that virtuous people should be happy and that vicious people should be unhappy. The local theory does not guarantee these outcomes. Since the theory treats desert as emerging from a series of mutually independent allocations, it is compatible with an overall outcome where the virtuous are unhappy, or unhappier than the vicious. This may suggest that the whole-life theory should be endorsed after all.

I admit to feeling the force of this objection and want to say three things in response. First, it would be a mistake for a proponent of the local theory to try to deflect it by making 'lifetime well-being' a separate sphere of desert. ${ }^{22}$ The sources of well-being are so diverse and all-encompassing that this will inevitably end up making the local theory either pointless or internally inconsistent. The whole-life theory and the local theory are rivals precisely because the local theory does not work with some kind of master desert. Second, the local theory is able to explain things that are somewhat similar to the idea that the virtuous deserve to fare better than the vicious. Consider Kolber's claim that 'good people deserve good things and bad people deserve bad things' (Kolber 2020, p. 190). The local theory can certainly explain that, because if good (bad) people are people who perform good (bad) actions, then they will come to deserve good (bad) treatment in different local contexts of desert. Indeed, we can even say something stronger. Because it is likely that a good person will attract positive desert in many situations, and a bad person negative desert, we can expect a society ruled by the local theory to lead to different overall outcomes for good and bad people even though there is no grand theory governing the whole scheme. This is certainly not the same as allocating happiness according to virtue, but it would be surprising if a faithful application of the local theory would produce, for example, a world in which the vicious are happier than the virtuous. Third, the very idea of happiness according to virtue looks less forceful once we seriously consider the local theory. If we had a perfectly devised local theory that were perfectly implemented, we would have a situation in which people are treated exactly as they deserve in each individual situation. It is not clear what would be missing from this picture as far as desert is concerned, apart from the fact that people may derive different amounts of happiness or unhappiness from their deserved grades, punishments, heartfelt thanks, and so on.

$\overline{22}$ This is arguably a mistake Sher (1987, pp. 132-149) makes. 
The idea of desert as a series of local allocations is also able to explain another intuition that is thought to speak in favor of the whole-life theory, namely our sense that past actions should matter for what someone deserves for a current act. To see this, suppose that offenders deserve punishments that are proportionate to the seriousness of their crimes. Suppose further that we are dealing with two men that have committed similar thefts, but whereas one man has committed numerous thefts in the past, the other is a first-time offender. Here it can seem odd to suggest, as the local theory would, that the two men deserve similar punishments. But note that if the local theory were faithfully implemented, then the repeat offender would have gotten what he deserved for each of his previous thefts. His slate would in that sense be wiped clean, making the idea that the two offenders now deserve similar punishments much more plausible. As this shows, when we consider the role of past actions in the local theory, it is important to be clear about whether we assess the theory under ideal or non-ideal circumstances, i.e. whether we assume that the theory is generally implemented or not (Rawls 1999, p. 8). ${ }^{23}$

But what would happen if the repeat offender did not get what he deserved for his previous thefts? Should he still be punished the same as the first-time offender? The question is ambiguous, because we need to know what the repeat offender is punished for. He certainly deserves punishment for the thefts he got away with, so from the point of view of local desert it would be good to punish him for these thefts now; and if the only way to do that would be for us to enhance his punishment for his latest theft, then doing so would also be good. ${ }^{24}$ It is another matter whether the previous thefts also mean that the repeat offender deserves a greater punishment for his latest theft. There are arguments on both sides here, but I tend to think that past offending does not make one's current crime any more serious. ${ }^{25}$ Hence, I would say that if the repeat offender were proportionately punished for his past thefts, he would not deserve a greater punishment for his latest theft compared to the first-time offender. To use the terms introduced in Sect. 2, this means that I would espouse a 'time-sliced' local approach rather than a 'diachronic' one. It is worth underlining that taking a time-sliced approach is not the same as ignoring past actions tout court, as the two thieves case demonstrates.

Let us finally consider the problem of credit served for wrongful conviction, which is interesting because it demonstrates how uncorrectable mistakes might be handled by the local theory. Consider the following case:

Robberies. Carl is prosecuted for robbing a bank. Carl is in fact innocent, but had he robbed the bank in the way alleged, he would have deserved five years.

\footnotetext{
23 The whole-life theory also fares better when considered as an ideal theory. For example, if Bert would be at the wellbeing level he deserved when he rescued the dog, then improving his well-being by praising him would be good from the point of view of whole-life desert (since his virtue improves by rescuing the $\operatorname{dog})$.

24 Note that I am speaking strictly about desert-based value here. There are obviously rule of law-related reasons why people should not be punished for crimes other than the ones prosecuted.

25 For a helpful overview of the debate, and an original argument for why repeat offenders are more culpable, see Lee (2009).
} 
The court mistakenly finds Carl guilty and sentences him to five years. The mistake is never detected and Carl serves the sentence in full. Upon release, Carl robs a bank in exactly the same way as the robbery for which he was mistakenly punished.

Suppose again that the local standard we endorse is that offenders deserve proportionate punishments. Kolber argues that this has implausible implications in Robberies, because if we were to look only at the seriousness of Carl's crime, Carl would end up spending ten years in prison, which would be more than he deserves. The conclusion Kolber draws is that retributivists need a wider account of desert if they are to handle credit for time served (Kolber 2020, pp. 193-94).

Two points can be made in response. First, taking Carl's undeserved punishment into account is not the same as taking all of his deeds into account, let alone his overall well-being. A retributivist could argue that Carl deserves a lenient punishment because of the wrongful conviction without having to say that he also deserves a lenient punishment in virtue of, say, being nice to pets or senior citizens. It would be a mistake to take the intuition that Carl deserves little or no punishment for the second robbery as evidence for the whole-life theory. To put things in proper perspective it should be noted that the whole-life theory can endorse things that a retributivist would find much more troubling than the idea of punishing Carl again, such as using punishment against innocent but undeservedly happy people.

Second, even if the local theory would say that Carl deserves five years for the second robbery, it is not clear that this result is objectionable. The local theory holds that Carl's desert for robbing the bank and for being mistakenly punished are two separate questions. Thus understood, there is no reason why Carl's compensation must come in the form of credit for time served in the first place. Carl most likely deserves a public apology plus a sizeable check from the government for the mistaken punishment, not a get-out-of-jail-free card.

Kolber responds that credit for time served 'would more accurately compensate' (Kolber 2020, p. 194). That may be so, but notice that the local theory's aim is not that Carl must end up no worse off. Kolber seems to assume that it would be a problem from the point of view of desert if Carl would be worse off in the situation where he robbed the second bank and was compensated compared to the counterfactual state of affairs in which he was never mistakenly punished in the first place. The local theory, however, rejects precisely this sort of fungibility between mutually independent allocations of desert. In terms of overall well-being, the compensation Carl deserves may well be insufficient to offset the punishment that Carl also, for independent reasons, deserves. The same would hold for offenders that are overpunished for their crimes. Overpunishment is regrettable, and grounds for compensation, but excessive punishment for a crime would not make a corresponding underpunishment for a future crime deserved. 


\section{Conclusion}

I have argued that the potential conflict between proportionality and desert in punishment is dissolved once retributivists adopt the local theory of desert. When deserved punishment is seen as a 'local' issue, nothing stops retributivists from endorsing proportionalism, i.e. the view that an offender morally deserves a proportionate punishment. If proportionalism is correct, the concern that proportionality calls for undeservedly harsh punishments goes away.

It is worth repeating that I have not offered positive arguments for why proportionalism is correct. My aim has merely been to clear a path for this approach. Determining the extent to which proportionality is a plausible standard of desert in the sphere of punishment is a topic for another day. While the substantive relationship between proportionality and desert no doubt raises difficult questions, following this paper we at least know two things: first, retributivists should reject the wholelife theory in favor of the local theory; second, once retributivists adopt the local theory, their defense of proportionality will be exactly as strong as the case for why people deserve proportionate punishments.

Acknowledgements Previous versions of the paper were presented online at meetings organized by Georgetown University, Aarhus University, and the University of Gothenburg. I am grateful for the comments I got during those events, especially from the authors that contribute to this special issue. I am also grateful for the extensive written comments I received from Kasper Lippert-Rasmussen and Søren Midtgaard. Finally, I would like to give special thanks John Hasnas and Douglas Husak for conceiving of the workshop on proportionality and for deciding to run it online after the pandemic hit.

Funding Open access funding provided by University of Gothenburg.

Open Access This article is licensed under a Creative Commons Attribution 4.0 International License, which permits use, sharing, adaptation, distribution and reproduction in any medium or format, as long as you give appropriate credit to the original author(s) and the source, provide a link to the Creative Commons licence, and indicate if changes were made. The images or other third party material in this article are included in the article's Creative Commons licence, unless indicated otherwise in a credit line to the material. If material is not included in the article's Creative Commons licence and your intended use is not permitted by statutory regulation or exceeds the permitted use, you will need to obtain permission directly from the copyright holder. To view a copy of this licence, visit http://creativecommons.org/licen ses/by/4.0/.

\section{References}

Alexander, Larry, and Kimberly Kessler Ferzan. 2009. Crime and Culpability. Cambridge: Cambridge University Press.

Berman, Mitchell. 2011. “Two Kinds of Retributivism.” In Philosophical Foundations of Criminal Law, edited by Antony Duff and Stuart Green. Oxford: Oxford University Press, 433-57.

Berman, Mitchell. 2013. "Rehabilitating Retributivism." Law and Philosophy 32 (1): 83-108.

Duff, Antony. 2001. Punishment, Communication, and Community. Oxford: Oxford University Press.

Duus-Otterström, Göran. 2013. "Why Retributivists Should Endorse Leniency in Punishment." Law and Philosophy 32 (4): 459-83.

Duus-Otterström, Göran. 2018. "Retributivism and Public Opinion: On the Context Sensitivity of Desert." Criminal Law and Philosophy 12 (1): 125-42. 
Duus-Otterström, Göran. 2020. "Weighing Relative and Absolute Proportionality in Punishment." In Of One-Eyed and Toothless Miscreants, edited by Michael Tonry. Oxford: Oxford University Press, $30-50$.

Duus-Otterström, Göran, and Erin I. Kelly. 2019. "Injustice and the Right to Punish.” Philosophy Compass 14 (2): 1-10.

Elster, Jon. 1990. “Local Justice.” European Journal of Sociology 31 (1): 117-40.

Feinberg, Joel. 1999. "Justice and Personal Desert." In What Do We Deserve?, edited by Louis Pojman and Owen McLeod. Oxford: Oxford University Press, 70-83.

Feldman, Fred, and Brad Skow. 2020. "Desert." In The Stanford Encyclopedia of Philosophy, edited by Edward N. Zalta, Winter 2020. https://plato.stanford.edu/archives/win2020/entries/desert/.

Fritz, Kyle G. 2019. "Hypocrisy, Inconsistency, and the Moral Standing of the State." Criminal Law and Philosophy 13 (2): 309-27.

Hirsch, Andrew von. 2009. "Proportionate Sentencing: A Desert Perspective." In Principled Sentencing: Readings on Theory and Policy, edited by Andrew Ashworth, Andrew von Hirsch, and Julian Roberts. Portland: Hart, 115-25.

Husak, Douglas. 2008. Overcriminalization. Oxford: Oxford University Press.

Husak, Douglas. 2016. "What Do Criminals Deserve?" In Legal, Moral and Metaphysical Truths: The Philosophy of Michael S. Moore, edited by Ferzan, Kimberly Kessler and Stephen J. Morse. Oxford: Oxford University Press.

Kagan, Shelly. 2012. The Geometry of Desert. New York: Oxford University Press.

Kolber, Adam. 2020. “The Time-Frame Challenge to Retributivism.” In Of One-Eyed and Toothless Miscreants, edited by Michael Tonry. Oxford: Oxford University Press, 183-208.

Lee, Youngjae. 2009. "Recidivism as Omission: A Relational Account." Texas Law Review 87: 571-622.

Matravers, Matt. 2020. "The Place of Proportionality in Penal Theory." In Of One-Eyed and Toothless Miscreants, edited by Michael Tonry. Oxford: Oxford University Press, 76-96.

Moore, Michael. 1998. Placing Blame. Oxford: Oxford University Press.

Moore, Michael. 2010. Causation and Responsibility: An Essay in Law, Morals, and Metaphysics. Oxford: Oxford University Press.

Olsaretti, Serena. 2003. "Introduction: Debating Desert and Justice." In Desert and Justice, edited by Serena Olsaretti. Oxford: Oxford University Press, 1-24.

Rawls, John. 1999. A Theory of Justice. Revised ed. Oxford: Oxford University Press.

Ross, David. 2002. The Right and the Good. Oxford: Oxford University Press.

Ryberg, Jesper. 2004. Proportionate Punishment: A Critical Investigation. New York: Kluwer Academic.

Ryberg, Jesper. 2020. "Proportionality and the Seriousness of Crimes." In Of One-Eyed and Toothless Miscreants, edited by Michael Tonry. Oxford: Oxford University Press, 51-75.

Sher, George. 1987. Desert. Princeton: Princeton University Press.

Tadros, Victor. 2011. The Ends of Harm: The Moral Foundations of Criminal Law. Oxford: Oxford University Press

Walzer, Michael. 1983. Spheres of Justice. New york: Basic Books.

Publisher's Note Springer Nature remains neutral with regard to jurisdictional claims in published maps and institutional affiliations. 